\title{
A Philosophical Analysis of Jacques Derrida's Contributions to Language and Meaning
}

\author{
John Gabriel Mendie ${ }^{1}$, Stephen Nwanaokuo Udofia ${ }^{2}$ \\ ${ }^{1}$ Department of Philosophy, University of Calabar, Nigeria \\ ${ }^{2}$ Department of Philosophy, University of Ibadan, Nigeria
}

Article History
Received:
29.05 .2020

Revised:
25.06 .2020
Accepted:
27.06 .2020
*Corresponding Author:
John Gabriel Mendie
Email:
jgmendie@gmail.com

\section{Article History}

Received:

Revised:

Accepted:

27.06.2020

John Gabriel Mendie

jgmendie@gmail.com
Abstract: Far from being a banality or a philosophical naivety, there is a quintessential nexus between language and meaning, in the philosophy of Jacques Derrida (1930-2004). The thrust of Derrida's idea is that, language is chaotic and meaning is never fixed, in a way that allows us to effectively determine it (that is, meaning is unstable, undecided, provisional and ever differed). As a Poststructuralist, Derrida's quarrel was with Logocentrism, which privileges speech over writing, and hitherto assume that, we have an idea in our minds, which our writing or speaking attempts to express. But, this, for Derrida, is not the case, for no one possesses the full significance of their words. Texts, in some sense write themselves: that is, are independent of an author or his intentions. Thus, in Derrida's thinking, intentionality does not play quite the same role, as is traditionally conceived in the philosophy of language; our intention does not determine the meaning of what we are saying. Instead, the meaning of the words we use, determines our intention, when we speak. This does not mean that we do not mean what we are saying, or that we cannot have intentions in communicating. But, since language is a social structure that developed long before and exists prior to our use of it as individuals, we have to learn to use it and tap into its web of meanings, in order to communicate with others; hence, the need for deconstruction. It is this process of deconstruction, which can point the way to an understanding of language, freed from all forms of structuralism, logocentrism, phonocentrism, phallogocentrism, the myth or metaphysics of presence and also open up a leeway, to the idea of différance. Thus, this paper, attempts an expository-philosophical analysis of Derrida's eclectic contributions to language and meaning, by drawing insights from his magnus opus, captioned De la grammatologie (of Grammatology).

Keyword: Jacques Derrida, Language, Phonocentrism, Phallogocentrism, Structuralism. 


\section{Introduction}

Jacques Derrida (1930-2004), was one of the greatest postmodern French philosophers of the 80s and 90 s, yet, many find it difficult to grasp his ideas. Derrida, raised complex philosophical questions about texts and textuality, and invented the tool of deconstruction, which emphasizes the necessary incompleteness of texts. That is, deconstruction is used to show that a work does not adequately address something. Derrida argues that, there are many possible interpretations of any given text, and readers can play with texts (like one plays with toys). This element of play, in Derrida's thinking, is significant because, what we get when we read a text is not an objective account of logos or even what the author really meant, but our present interpretation or understanding of the text itself. This understanding becomes, so to speak, our own [text] of the text. Thus, Derrida jettisons the idea that the meaning of a text does not change, by challenging the author's intentions, and showing that there may be numerous reasonable interpretations of a text (this, is where the idea of 'the author is dead' arises: for, once the text is written, the author's input, loses its significance). In Derrida's understanding, the text becomes open at both ends, that is, the text has no stable identity, no stable origin, and no stable end. Each act of reading the "text" is a preface to the next [1]. Derrida, has contributed immensely to various areas of study, through a plethora of turgid and often misunderstood, writings. In philosophy of language, it was De la grammatologie (Of Grammatology). It is here that, Derrida entered upon a brilliant deconstruction of the accounts of language given by Ferdinand de Saussure (1857-1913) [2], Claude Lévi-Strauss (1908-2009), Jean-Jacques Rousseau (1712-1778) and others. With his method of deconstruction, Derrida provided critiques, not only of literary trends and philosophical ideas, but also of political institutions. He won many followers among humanists, but analytical philosophers tended to be skeptical that Deconstructionism was anything more than a fancy name for a mélange of half-understood ideas.

Notwithstanding, Derrida's theory of the sign and free play of signifiers, fits into the poststructuralist movement, which runs in contradistinction to the legacy of Saussurean structuralism. Maintaining that the signifier (the form of a sign) refers directly to the signified (the content of a sign), structuralist theory has passed down a whole current of logocentric (speech-centred) thought that originated in the time of Plato, Wilson [3] which favours deterministic structural forces, over the ability of people to embrace the fundamental ambiguity of language, and thus, is in dire need of deconstruction. With writing as his basis (the written sign), Derrida has taken on the task of disrupting the entire stream of metaphysical thought predicated on oppositions [4] has elaborated a theory of deconstruction (of discourse, and therefore of the world) that challenges the idea of a frozen structure and advances the notion that there is no structure or centre, no univocal meaning. The notion of a direct relationship between signifier and signified is no longer tenable, and instead we have infinite shifts in meaning, relayed from one signifier to another. Language itself, is menaced in its very life; helpless, adrift in the threat of limit-lessness, brought back to its own finitude at the very moment when its limits seem to disappear, when it ceases to be self-assured, contained, and guaranteed by the infinite signifier which seem to exceed it. As a distinguished poststructuralist and a kin antagonist of logocentricism, Derrida, maintains that words, refer only to other words, not to things or thoughts or feelings. His deconstruction is employed by radical critics to question or undermine the canon of western literature [5]. Thus, Derrida took a hermetic view of language, which fuelled his age long fight against structuralism and Logocentrism [6]. But, as one would readily notice, Derrida, is reacting to all forms of envisaged fixity, or dogmatic absolutism, with regards to language and meaning. This tendency for pluralism, heterogeneity and difference, is characteristic of the postmodern thinking stream, which Derrida belongs. And so, to understand Derrida's thoughts in the right perspective, an excurses into the historiography of Derrida's emergence in the history of philosophy, is apposite.

\section{Background to Derrida's Emergence in the History of Philosophy}

The history of philosophy is often characterized by different epochs, with different themes, taking centre stage of their respective discursive formations. Its periodization, begins with the ancient, medieval, modern, down to the postmodern, depending on the available literature one chooses to follow [7]. A detailed analysis of this catalogue of history, would not be our focus in this paper. What is of interest to us, is to situate Jacques Derrida's philosophy, within the highlighted epochs. For this reason, we shall limit ourselves to the Modern and Postmodern periods. But what is Modernism? Who are the Modernists? What was the project of the Modernists, that is, what were they for and what were they against? Now, suffice it to say that the Modern Period, was a phase in the history of philosophy 
[8], characterized by the values and doctrines of the Enlightenment [8]. It was a period, where reason was idolized. Reason, here, refers to a particular way of reasoning, a particular model (of rationality) for the conception of reality. Philosophers of the Modern period (like René Descartes, John Locke, John Rawls, Jean-Jacques Rousseau and so on), emphasized, a universal, objective, fundamental, fixed, determined, grand totalizing, determinate, definite and definitive way of conceiving reality. In their formulations, they seemed to privilege, homogeneity, singularity and oneness, which, underscores the idea of finality (' $T H E$ ' method). It is against this very idea of singularity and the craze for a fixed, absolute and objective standard, which gave rise to the emergence of the postmodern philosophers.

Accordingly, the "post" in the postmodern (as Jean-François Lyotard admonishes), means: "beyond or after" the Modern; or "against" the values, concepts, precepts, and principles of the modern Period [8]. The Postmodern philosophers were against the chants of objectivity, fixity, universality, absolutism, and singularity of method, herald by the modern philosophers. In William Lawhead's thinking, postmodernists are a loose-knit group of thinkers, united around the belief that they are the pallbearers of the modern tradition that originated in the Enlightenment [9]. The tradition of modernism they reject includes the following beliefs: there is one true picture of reality; it is possible to obtain universal, objective knowledge; science, is a superior form of knowledge; the history of modern thought has been a cumulative progression of increasingly better theories about reality; and the autonomous, knowing subject is the source of all ideas [9]. Against this backdrop, the postmodern thinkers set out to unmask the pretensions of reason and the illusions of metaphysics. For these thinkers, the dream of finding a central theme or set of categories for understanding reality is now over. There are no essences or certitudes on which we can pin our hopes. We must now face our stark, uncharted waking experience for the first time. We are the products of history, and history is nothing but an aimless play of shifting social forces. What is left for us to do, is to analyze or 'deconstruct' the dream of reason, to see how it arose and why it seemed so real, or else to revel in the endless play of interpretations and perspectives, realizing that it is a game without a final goal [9].

For these reasons, postmodernists frequently allude to the death of epistemology (foundationalism), the death of metaphysics, and even the death of philosophy, at least as it has traditionally been understood. Thus, their project can be summed up cursorily in the following ways: deconstruction of objectivity (no objective reality); privileging pluralism or multiculturalism (truth is relative/subjective); united against method (challenges modernity's view of the world); acknowledging heterogeneity (reality is human construct); celebration of difference (meaning is provisional); and the joint approval of eclecticism. In their resolve, they all muse: let all flowers blossom together.

The most frequently discussed postmodernists in currency include: Michel Foucault, Richard Rorty, Paul K. Feyerabend, Jacques Derrida, and so on. As can be seen in the analysis above, Jacques Derrida, can be situated within the postmodern era. This postmodern temperament and character, seems to have been replicated in virtually all of Derrida's works, such as: Of Grammatology (1967), Writing and Difference (1967), Margins of Philosophy (1972), Dissemination (1972), The Truth in Painting (1978), Memoirs of the Blind (1990), Spectres of Marx (1993), and so on [10]. Jacques Derrida is also known as a post-structuralist thinker, due to his attempt to deconstruct the accounts of language given by Ferdinand de Saussure and Claude Lévi-Strauss, in form of structuralism. (Mastin, L. 2008.) According to Derek Johnston, structuralism is a philosophical and methodological outlook which was fashionable in the 1960s. It is a method of studying language, society and the works of artists and novelists. Its main teaching is that reality is composed of relationships rather than things [10]. The structuralists (like Ferdinand de Saussure), when we see, feel, smell, consider any object, it is there, in so far as we perceive it, but it is also not there, in so far as its reality is also composed of its relation to 'the whole system' [11]. A whole web of relationships existing at any given time and of which each percipient could not be aware.

Structuralism tends to divide our perception of the world into binary categories, minimal pairs: good/bad, right/wrong, cooked/raw, true/untrue, male/female, light/dark, left/right, fact/fiction, nature/nurture, and so on [10]. It analyzes the structures that lie behind or beneath things. It tends to distrust history and concentrates instead on web of patterns holding at any given time. It is these assumptions of structuralism and Logocentrism, which Derrida seeks to rebuff. Yet the choice of "writing" is also polemical, against the manifest phonocentrism of structuralism. And this is precisely what has sometimes led to that general misunderstanding, or to the hasty view that Derrida, seems to 
be restoring priority to writing over speech in the study of language. But this is, of course, a very hasty view. A careful reading of his Of Grammatology, shows quickly that what Derrida rather points out, is that speech too-grafted within an empirical context, within the structure of speaker-listener, within the general context of the language, and the possibility of the absence of the speaker-listener, is structured as writing; that in this general sense, there is "writing in speech" [12]. Thus, in Derrida, we come to a most interesting and controversial philosopher of language, meaning and text. We now turn our beam, to the essentials of Derrida's contributions to language and meaning.

\section{Fundamentals of Derrida's Contributions to Language and Meaning}

For a subterranean adumbration of the essentials of Jacques Derrida's contributions to Language and meaning, it is congenial to raise the following questions: what is Derrida against? What is he for? And how did he set out, to accomplish his mission? Derrida's contribution, fits into the poststructuralist movement, which runs counter to Saussurean structuralism (the legacy of the Swiss linguist Ferdinand de Saussure) and that of anthropologist Claude Levi-Strauss. Maintaining that the signifier (the form of a sign) refers directly to the signified (the content of a sign), structuralist theory, has passed down a whole current of logocentric (speech-centred) thought that originated in the time of Plato. With writing as his basis (the written sign), Derrida has taken on the task of disrupting the entire stream of metaphysical thought predicated on oppositions. Derrida has elaborated a theory of deconstruction (of discourse, and therefore of the world) that challenges the idea of a frozen structure and advances the notion that, there is no structure or centre, no univocal meaning. The notion of a direct relationship between signifier and signified is no longer tenable, and instead we have infinite shifts in meaning relayed from one signifier to another [13].

To ground his philosophy, Derrida introduces some key terms, which are quintessential to this paper. They include terms such as: logocentrism; binary oppositions; phonocentrism; arche-writing; metaphysics of presence (or myth of presence); Supplementation; Trace; "sous rature" (under erasure) and Différance, just to mention a few. We shall endeavor to show how these terms are implicated in Derrida's cogitations. From existing literary sources, it would seem that, the main project of Derrida is to deflate the pretensions of reason that are manifested throughout the history of thought. Derrida believes that, the entire history of philosophy is a series of variations on the myth (or metaphysics) of presence. In other words, every philosophy starts by assuming some central presence, which is the axis around which the whole system revolves [9]. Additionally, Derrida, believes that the great minds of Western civilization had a distorting bias in all their thought and writing. This was a bias in favour of speech and against writing. He called this type of writing 'logocentric' and claimed that, it was in need of deconstruction.

Put very crudely, logocentrism is the idea that we can get to the very essence of meaning when we succeed in choosing the right word for the idea. If we speak, we are at one remove from an idea, if we write, we are at two removes from an idea [10], and so, speech is prioritized over writing, because here we are closer to the essence of meaning. Such fixed meanings can be known with certainty through the use of human reason. This was the idea that Derrida was outrightly attacking. Derrida also believed that the desire for certainty, had held Western intellectual life and thought, in a tyrannical grip, by excluding everything that cannot be known with certainty. This has at times, included poetry, ethics and mysticism. Derrida alleged that such an attitude was part of the tyranny of logocentrism. Most people think that, if we do not have a word for something it does not exist. A word is necessary to perceive a thing as it is. Controlling language is controlling things. What more, logocentrism tends to give greater value to one of the two poles of binary opposites: light over dark, fact over fiction, cooked over raw, male over female, capital over labour, and occasionally indeed, the other way around [13].

Logocentrism occurs, when we give the spoken word more importance than the written word. Speaking, (in logocentric terms) is a sign of presence; when we speak to somebody, they are with us. While writing, is a sign of absence; we write to somebody because, they are at a remove (distance). The more words are shut away in writing, logocentrism maintains, the more they are copies rather than the real thing. Derrida attacks this 'myth or metaphysics of presence', and subsequently, rebuts the notion that speech has priority over writing. Derrida's raison d'etre for this attack is that, both forms of language are signs; both exhibit partial absence and partial presence, which is to say that both are relational. In fact, those who attack writing, on the basis that it is derivative, do so, by conducting their attacks in writing. And so, when Derrida attacks the priority of speech over writing, 
he is attacking the notion of any sort of absolute. Both speech and writing are signs; they are useful because, they can be used over and over again; we never come close to an original presence or meaning. Thus, language is a partial presence and a partial absence [10]. The suggestion then, is that this phonocentrism-logocentrism, relates to centrism itself- which is the human desire to posit a "central" presence at beginning and end.

\section{As Derrida poignantly observes [1]:}

The notion of the sign...remains within the heritage of that logocentrism which is also a phonocentrism: absolute proximity of voice and being, of voice and the meaning of being, of voice and the ideality of meaning...We already have a foreboding that phonocentrism merges with the historical determination of the meaning of being in general as presence, with all the sub-determinations which depend on this general form...(presence of the thing to the sight as eidos, presence as substance/essence/existence (ousia), temporal presence as point (stigme) of the now or of the moment (nun), the self-presence of the cogito, consciousness, subjectivity, the co-presence of the other and of the self, inter-subjectivity as the intentional phenomenon of the ego, and so forth). Logocentrism would thus support, the determination of the being of the entity as presence.

As a literary critic, Derrida's trouble with logocentrism, is better apotheosized and brought to the glare of publicity, with his idea of 'play'. By 'play' Derrida means openness to unexplored possibilities and novel approaches. In seeking to anchor thought and language in a 'center,' the philosopher limits and freezes our modes of interpretation, seeking security in a foundation that will not fail us. Derrida's strategy is not to refute these claims, but to unmask them by exposing the underlying motives and illusions that animate them all. Derrida calls this process "deconstruction" and its result is a 'decentering' of our systems of thought [9]. Mutually, with Friedrich Nietzsche and Michel Foucault, Derrida rejects logocentrism or the notion that language refers to an order of meaning and truth, an order that is based on a reality that exists independently of our historically relative perspectives. However, if there is no certainty, no possibility of finding the center, no meanings or universals, external to the language we invent, then everything is interpretation. The logical conclusion of this position is that all we ever achieve are reinterpretations of interpretations. Thus, language is twisted and bent even as it guides us, and meaning is only provisional.

In the ipsissima verba of Derrida, he writes [1]:

Reading...cannot legitimately transgress the text toward something other than it, toward the referent (a reality that is metaphysical, historical, psychobiographical, and so on), or toward a signifier outside the text whose content could take place, could have taken place outside of language, that is to say, in the sense that we give here to that word, outside of writing in general... There is nothing outside of the text (il n'y a pas de hors-texte).

Assuming that language cannot refer beyond itself, Derrida concludes that the meaning of a term is the function of the place it occupies within a system of linguistic concepts. More specifically, terms receive their meanings from the role they play, in differentiating one category of things from another. For example, nature does not present us with any absolute divisions corresponding to the terms 'warm' or 'hot', anymore that it does for the contrasting terms of masculine/feminine or normal/abnormal. Instead, Derrida claims that, all such terms receive their meanings from the distinction that are created within language.

From the premise that language has no absolute, external point of reference, Derrida concludes that language is arbitrary, imposing no limits on the play of meanings, and interpretations, readers may find in a text. It is from this vantage point, that Decontructionists seek to reveal the incoherencies within texts, for from the conflict of multiple interpretations new possibilities of interpretations are generated. Nevertheless, to take his theorizations to its crescendo, Derrida, introduces a French pun with the word 'différance.' This (word) has the tripartite meaning of: "differ", "defer" and "detour" [1]. The verb 'différer', present participle 'différant', means to put off, to delay. It is out of these two words, that Derrida, invented 'différance.' This new word is intended to cover all the meanings, which are left out by the fact that the word, does not exist. This new word does not stand for a new concept; rather, it plays around the notion of undecidability, provisionality, temporality or ad interim. Language, thought and meaning, are now all in an uncomfortable position: they are unstable. They 
force us to ask ourselves, if language can be relied upon, since a final decision on meaning, will have to be postponed. Because, words do not have a fixed, positive meaning, but meaning emerges from the way they differ, then, we have to continually defer any final interpretation or assignment of meaning (meaning is never immediate; it is always deferred).

For Derrida, undecidability, is in fact an element of the philosophy of the Western tradition, but, the tradition, refuses to recognize this basic fact. There are many words in the Western tradition that are ambiguous, can be interpreted in a good or bad sense. Texts, frequently fail to note this ambiguity and so, cut out one of the binary poles of meaning. In English, 'drug' is an example; it has a use that suggests therapy and a use that suggest undisciplined abuse, even enforced narcotic 'absence.' In Derrida's thinking, writing, has qualities that disrupt structuralist opposites. Words, are of course, never univocal. They never have one meaning and one meaning only, which is fixed and will never change. For instance, the word 'pen' [10], can mean a writing instrument, a female swan, a small enclosure for animals; in the USA, it is used as short form, for 'penitentiary' (a prison); in the Caribbean, it can mean a cattle farm and also a fortified dock for submarines [10]. The context will usually give us the sense. However, some language differences are so subtle, we slip from one to the other, and back again without noticing. But, the example above, and many others, left unmentioned, only shows that there is a basic undecidability about language. We can never get to final bedrock or foundational meaning.

Derrida's arguments are not close-knit, as one would expect. His method, rather trawled through texts of philosophers like, Plato, Husserl, and linguists such as, Ferdinand de Saussure and LeviStrauss, noting where undecidables were at work, where the text was unsure of itself. Through this method, Derrida claims to be undermining the foundations of Western rationalist metaphysics. On the whole, this approach is meant to show that, once language enters the public domain, the speaker or writer loses control over it. This is evident in the way a new book, a novel for instance, a film or a song, is understood, interpreted or misinterpreted by the reviewers immediately after it appears (or is brought to the glare of publicity). In the literary world, there is this tendency to develop a technique for dealing with words or sentences that could have several meanings. We try to put the word into context, but will context always be able to provide meaning? Laws or rules, for instance, are passed within certain contexts in mind. But, what happens, if a law which is passed with one set of contexts in mind, has to be applied in a totally different situation that no legislator could have imagined? This brings us to writing and iterability, where Derrida, sees writing as 'iterable', that is, repeatable with difference. Writing is always eventually cut free from its sender and the person to whom it is addressed. It is then read, frequently with different results, by third parties for whom it could never have been intended. Language is like a ghost, it is continuously repeated as it is; though it appears different on each occasion. When applied to 'text' or 'text play', all we see is a series of 'traces' which cannot be reduced to the very materiality of the resulting written object, although, in Derrida's parlance: "there is nothing outside the text" [1].

Language, therefore, cannot refer beyond itself, since; the meaning of a term is the function of the place it occupies within a system of linguistic concepts [1]. With regards to words, which, escapes the instituting question of philosophy (like being/is), there is, a certain philosophical exigency that drives Derrida to writing or introducing "sous rature", which is translated as "under erasure" [1]. This means, to write a word, cross it out, and then print both word and deletion. It is meant to show its inaccuracy, unseriousness, and the idea of 'play', as employed by Derrida in deconstruction of texts. But, since the word is 'inaccurate', it is crossed out, and since it is necessary, it remains legible [1].

According to Peter Benson, Derrida emphasizes a further necessary characteristic of the linguistic mark: its capacity for iteration (as mentioned above), and by this he means that, the mark must, in principle, be repeatable, and be recognized as 'the same' in each repetition. Each repetition will differ to some extent, but ' $a$ ', ' $A$ ', and ' $A$ ' must all be recognized as the same letter. It is this, which lifts the mark from its material particularity into being an instance of a universal. As Derrida notes, even a signature, that proof of individuality and identity, must be capable of being repeated, lest its value, its capacity for being recognized, be lost. When the mark of my identity takes a linguistic form it becomes repeatable beyond my control, beyond my absence, beyond my death [14]. Hence an attention to writing as the exemplary manifestation of language reveals the minimal unit of language (which Derrida calls "the gramme" - thus, his word 'grammatology') to be always an iterable trace. As earlier mentioned, a 'trace' is a mark remaining after the moment of its inscription; it is, the aftereffect of différance. 
In French, the word 'trace' also carries as one of its connotations the idea of a trail left by an animal that a hunter might follow. These footprints or flattened foliage indicate the animal (the producer of the gramme) that has now passed; they remain there whether the hunter (the receiver of the gramme) arrives on the scene or not; and it is always possible that their significance may fail to be read (by an inexperienced tracker). So, the trail like the grammè, conjures forth what is absent (producer, receiver, and message). This is a striking quality for any entity to have. In general, things are what they are, and nothing else (self-contained elements of existence). But a grammè (once it is recognized as being a grammè) also brings with it the shadows of things, it is not [14]. This leads us to what Derrida calls supplementarity. With respect to signifier(s) and the signified(s), the supplement must be thought as having two mutually exclusive meanings. First, it is a replacement (that is, replacing the absent center); second, it is an addition, (adding something new to the structure itself). The point is that, for Derrida, there is a remainder (an excess) of signification always remaining 'unsignified' (a lack of signification), which allows new readings in new contexts. This realization prompts Derrida, to come down neither on the side of structure, nor on the side of play, but locates at the absent center, a process that he names différance.

\section{As Derrida conceives it [1]:}

We must begin wherever we are, and the thought of the trace, which 'cannot not' take the scent into account, has already taught us that it was impossible to justify a point of departure absolutely. Wherever we are: in a text where we already believe ourselves to be...That Dangerous Supplement.

In certain respects, the theme of supplementarity is certainly no more than one theme among others. It is in a chain, carried by it. Perhaps, one could substitute something else for it. But it happens that this theme describes the chain itself, the being-chain of a textual chain, the structure of substitution, the articulation of desire and of language, the logic of all conceptual oppositions, and particularly the role and the function, it plays in linguistic system. It tells us in a text, what a text is, it tells us in writing what writing it.

If we consider, according to the axial proposition of any essay or text, that there is nothing outside the text, our ultimate justification would be the following: the concept of the supplement and the theory of writing, designate textuality itself in any identifiable text, in an indefinitely multiplied structure- en abyme (in an abyss) [1]. An entire theory of the structural necessity of the abyss will be gradually constituted in our reading; the indefinite process of supplementarity has always already infiltrated presence, always already inscribed there, the space of repetition and the splitting of the self. Representation in the abyss of presence is not an accident of presence. The desire of presence is, on the contrary, born from the abyss (the indefinite multiplication) of representation, from the representation of representation, and so on [1]. Thus, the supplement itself is quite exorbitant, in every sense of the word. From the ex post facto, it is evident that Jacques Derrida, employs a plethora of terms in the delineation of language and meaning, especially, as it relates to deconstruction of texts. But what is deconstruction and how is it implicated in Derrida's theorizations? As would be readily shown, the whole idea of deconstruction, is germane to this paper, but before we attempt a synopsis of Derrida's deconstruction project, it is apposite, to cursorily reiterate the concepts espoused above, for an integrated understanding. We begin with the notion of Différance. The word seems to be an improvement of Saussure's idea that, language does possessed differences [3] différance really means is that a text or a particular word, can have different meanings (two or more). Derrida uses the term to assess Martin Heidegger's notion of ontological difference between 'Being' and 'being'.

In his delineation, Derrida writes [15]:

It is the domination of beings, that différance everywhere comes to solicit, in the sense that sollicitare, in old Latin, means to shake as a whole, to make tremble in entirety. Therefore, it is the determination of 'Being' as presence or as beingness, that is interrogated by the thought of différance. Such a question could not emerge and be understood unless the difference between 'Being' and 'beings' were somewhere to be broached. First consequence: différance is not. It is not a present 'being', however excellent, unique, principal, or transcendent. It governs nothing, reigns over nothing, and nowhere exercises any authority. It is not announced by any capital letter. Not 
only is there no kingdom of différance, but différance, instigates the subversion of every kingdom...Since 'Being' has never had a 'meaning', has never been thought or said as such, except by dissimulating itself in beings, then différance, in a certain and very strange way, (is) 'older' than the ontological difference or than the truth of 'Being'.

This is suggestive of the notion that, Différance, is the productive movement of differing and deferring. Every concept is deferred in signifying plenitude, without realization, and differed in gaining identity from that which it is not. Différance is not a concept, but that which makes concepts possible. It is not an essence, for it assumes a different form in each relation and does not exist before these [3]. Thus, as soon as there is meaning, there is difference [16]. Next, is the idea of Trace. Now, it is important to note that, these notions are linked together. The idea of différance also brings with it the idea of trace. A trace is that from which a sign differs/defers; it is the absent part of the sign's presence. In other words, through différance, a sign leaves behind a trace, which is, whatever is left over, after everything present has been accounted for.

According to Derrida, the trace itself is not existence, because, it is quiet; thus, in presenting itself, it becomes obliterated. As Derrida observes rather expressively: "the unheard difference between the appearing and the appearance (l'apparaissant et l'apparaitre), that is, between the "world" and "lived experience", is the condition of all other differences, of all other traces, and it is already a trace [1]. Another quintessential term employed by Derrida is arche-writing (archi-écriture) [1]. In deconstruction, the word écriture (writing) is appropriated to refer not just to systems of graphic communication, but to all systems inhabited by différance. A related term, called archi-écriture, refers to the positive side of writing, or writing as an ultimate principle, rather than, as a derivative of logos (speech). In other words, whereas the Western logos encompasses writing, it is equally valid to view archi-écriture as encompassing the logos, and therefore speech can be thought of as a form of writing: writing on air waves, or on the memory of the listener or recording device, but there is no fundamental dominance at work. This, as described above, is an element of Derrida's criticisms against phallogocentrism (privileging of the masculine, in the construction of meaning) [17]. In general. The notion of Supplement, originary lack, and invagination, lurk as crucial linkages to understanding Derrida. The word supplement is taken from the philosopher Jean-Jacques Rousseau, who defined it as an unnecessary extra, added to something that is complete in itself.

According to Derrida, Western thought is characterized by the logic of supplementation, which is, in actual sense two contradictory ideas/poles. From one perspective, a supplement serves to enhance the presence of something which is already complete and self-sufficient. In Derrida's thinking, the western philosophical tradition of 'written' is a supplement. Thus, he writes: "if supplementarity is a necessarily indefinite process, writing, is the supplement par excellence, since it proposes itself, as the supplement of the supplement, sign of a sign; taking the place of a speech already significant [1]. Consequently, to Derrida, the Western notion of the supplement, has within it, the idea that a thing, that has a supplement cannot be truly complete in itself. If it were complete without the supplement, it will not need, or beg for, the supplement. The fact that a thing can be added to make it even more present or whole, means that, there is a vacuum [1] (what Derrida calls an originary lack) and the supplement can fill that hole. The metaphorical opening of this vacuum Derrida captions "invagination". From this perspective, the supplement does not enhance something's presence, but rather underscores its absence. Thus, what really happens during supplementation is that something appears from one perspective to be whole, complete, and self-sufficient, with the supplement acting as an external appendage. However, from another perspective, the supplement also fills a vacuum within the interior of the original content. The supplement, therefore, represents indeterminacy between externality and interiority. All these, terminologies are appropriated by Derrida to deconstruct ancient (Greek) texts [5] with the view of showing the indecidability status and unstable nature of meaning. We now turn our beam to unearthing the nitty-gritty of Derrida's view on deconstruction, in relation to language, texts and meaning.

\section{Derrida's Deconstruction Project: Meaning, Nature and Significance}

The term 'deconstruction' derives from the work of Jacques Derrida [3]. It has been interpreted to mean a plethora of things. But, garnering insights from available literature, deconstruction, can be seen as a tool, which challenges structuralist assumptions that, a text's meaning can be discovered 
through an examination of its structural codes. Deconstruction seems to operate under the maxim of undecidability, and is motivated by the aeviternal urge for a decentralization of texts, by asking new set of questions, to show that what a text claims it says, and what it actually says, are different. Deconstruction seems to cast doubts on previously held theories, which seeks to find meaning(s) in a text, thereby declaring that a text has an almost infinite number of possible interpretations. It discovers binary oppositions that govern a text; comment on values, concepts, ideas beyond the binaries; reverse these binaries; dismantle previously held worldviews; accept possibilities of various perspectives or levels of meaning and allows meaning to be provisional and undecidable [18]. Thus, Derrida's concept of "deconstruction" lurks as a method of "reading" texts in order to find and expose the binary opposites immanent in the text's claims to truth, meaning, authority and authenticity.

Deconstruction seems to involve three main operations: first, finding the core binary at work in the text's construction; second, exposing the category that is privileged in the binary (the logos) and upon which the truth claim is based, as well as exposing the secondary, debased category (or the appurtenance); third, using the very terms of the truth claim to invert the binary, showing how an equally valid truth claim can be made, if the logos is decentred, and the appurtenance becomes privileged [19]. This last move is not merely to invert the binary opposition permanently and make the underprivileged category "win" over the privileged category; that new, inverted order would only become a new logocentric truth claim. Rather, the whole point of deconstruction is to show how truth and meaning are always unstable and contingent, brought into existence by force; by stabilizing or fixing a meaning (based on a binarism) in place and by the elevation of a privileged category, within the binary and the simultaneous suppression of its opposite. Deconstruction is a way to critique regimes of truth, by way of showing how this truth is always based on logocentrism. Derrida does not suggest that we can escape logocentrism (without it, there would be no truth, no meaning in the world), but, he seems to suggest that deconstruction, can become a powerful tool in challenging transcendental ideas that support regimes of (fixed, stable and immutable) truth in philosophy. Deconstruction is not synonymous with 'destruction'. It is in fact much closer to the original meaning of the word 'analysis', which etymologically means 'to undo'. For this reason, the deconstruction of a text does not proceed by random doubt or arbitrary subversion, but by the careful teasing out of warring forces of signification within the text. For as Derrida, often intones: "il n'y a pas de horstexte"- there is nothing outside the text (or there is no outside-text) [1].

Nevertheless, as a theory of criticism, the nature and significance of deconstruction, is such that questions traditional, foundational, grand totalizing norms and pattern of assumptions, about certainty, identity, meaning, and truth. It holds that words can only refer to other words. Deconstruction, is an attempt to demonstrate how statements about any text, destabilize their own meanings. Although Jacques Derrida refuses to define what deconstruction is, or of being associated with such a nick name [20], perhaps for fear of being pinned down or of undermining his astute project, he however, writes in several pages of his works to show that the term, Deconstruction, has no definite definition.

When asked: what is deconstruction? He avers:

Deconstruction is nothing of course [21]. Deconstruction doesn't consist in a set of theorems, axioms, tools, rules, techniques, methods...there is no deconstruction, deconstruction has no specific object ... [22]. Deconstruction is neither an analysis nor a critique...I would say the same about method. Deconstruction is not a method and cannot be transformed into one...It must also be made clear that deconstruction is not even an act or an operation...deconstruction loses nothing from admitting that it is impossible [21].

From the analysis above, it would seem that, the deconstructive process, comes not from the reader/critic, but from the text itself; it is already there, it is the tension "between what [the text] manifestly means to say and what it is nonetheless constrained to mean" [23]. To say that deconstruction is impossible, as Derrida seems to hold, is therefore to acknowledge the impossible desire of language, to make present the permanently elusive [24]. There is no method to deconstruction, because texts literally, deconstruct themselves in their impossible attempt to employ language as a 'transcendental signifier' [25], that is, as a way of 'pointing' at some eternal truth or other. As Gayatri Spivak, observes: "all texts, are rehearsing their grammatological structure, selfdeconstructing as they constitute themselves" [1]. Deconstruction, is therefore seen, not as a system, but an ensemble of rules for reading, interpretation and writing. 
Although, it is not entirely clear what these rules might be, Spivak, gives us some clues in her 'Translator's Preface' to Of Grammatology thus [1]:

To locate the promising marginal text; to disclose the undecidable moment; to pry it loose with the positive lever of the signifier; to reverse the resident hierarchy, only to displace it; to dismantle in order to reconstitute what is always already inscribed. Deconstruction in a nutshell.

From the above, it would seem that, deconstruction acts as a constant reminder of the ways in which language deflects or complicates the philosopher's project [26]. No wonder, Derrida claims that all of his essays were attempts to define what deconstruction is [27], and that deconstruction is necessarily complicated and difficult to elucidate, since, it vigorously evaluates the very language needed to expound it. Above all, deconstruction, works to undo the idea (in Derrida's parlance, the ruling illusion of Western metaphysics), that reason can somehow dispense with language and achieve knowledge ideally unaffected by such mere linguistic foibles. Though philosophy strives to efface its textual character, the signs of that struggle, are there to be read in its blind-spots of metaphor and other rhetorical strategies [26].

\section{Derrida and the "Free Play" Of Signifiers}

Armed with the tools of deconstruction, Jacques Derrida, navigates his drone to the adumbration of the seemingly fixed relationship that exists among sign, signifier and the signified (s). For Derrida, the relationship we find in structuralism between signifier and signified no longer exists. Truth is based on language, but, language is not a fixed system (the way structuralists conceive of it). Language is immanently chaotic, and words not only have different meanings and uses; but words (signifiers) themselves, do not simply correspond with their definitional meanings (signifieds). This is because, more often than not, these meanings are dependent on other signifiers.

For example, when a reader looks up a dictionary definition of a word, he or she does not find the signified of it, but, is only confronted with more words (more signifiers) that try to explain that original word. For this reason, Derrida argues that language is not (as structuralists assume), dependent on a correspondence between established codes and the fixed meanings attached to them, but that language exists in an unstable, "free play" of signifiers [1]. It is only through what he calls "violence" [1] (the kind of violence that freezes a binary opposition in place and institutes logocentrism) that a word can gain a fixed meaning.

Words are constantly threatened by the encroachment of new or unexpected meanings, words constantly evoke other words and meanings (rather than merely reflecting their own, exclusive meanings). For this reason, the signifier does not correspond to its signified, but slips easily into free play: even its dictionary meaning evokes so many 'signifieds' that slip, slide and flow in an unstable manner.

Let's consider the example of "water" as diagrammatically represented in Figure 1.

\begin{tabular}{|l|l|l|}
\hline & Water Drops & Swimming Pool \\
\hline Signifier (Water) & Lakes & Rain \\
\hline H2O & Glass of Water
\end{tabular}

Figure 1. "water" as Diagrammatically

From the schema in Figure 1, when reading the word "water", we might think of water drops, a lake, the chemical symbol $\mathrm{H} 2 \mathrm{O}$, and so on. We do not necessarily think of a set-image of water, a universal mental representation of it. And then, each concept (signifier) to which "water" might refer, can trigger another signifier. This infinite chain from signifier to signifier, results in a never-ending (indefinite) game, opens the text, displaces it, and sets it in motion.

Thus, this slipping and sliding of signifiers, over each other without ever reaching a signified (a ground or an end-point for stable thought or for the emergence of truth), lurks as the quintessential 
Derridean vision of language. Indeed, meaning is not inherent in signs; neither does it dwell behind the outward appearance of signs.

Commenting on this interplay of sign, signifier and signified, Derrida avows [1]:

The formal essence of the signified is presence, and the privilege of its proximity to the logos as phone is the privilege of presence. This is the inevitable response as soon as one asks: what is the sign? That is, when one submits the sign to the question of essence: to the ti esti. The "formal essence" of the sign can only be determined in terms of presence. One cannot get around that response, except by challenging the very form of the question and beginning to think that the sign is that ill-named thing, the only one, that escapes the instituting question of philosophy: what is (quel est)...?

Thinkers influenced by structural linguistics, have consistently pointed out that meaning is the result of the relationships between signs. But Derrida navigates further, by envisioning that the structures of meaning, must include the people who seek and create meaning. Since there is no rational vantage-point outside meaning, from which we can assess it 'scientifically', we, the seekers after meaning, are involved in the meanings which we create [10].

\section{Objections to Derrida's Contribution to Language and Meaning}

Reading the writings of Jacques Derrida, especially those with strong linkages with language and meaning, one would readily discover the turgidity and fluidity of words, as employed by Derrida. At one point, he seems to suggest one idea and at another point, he seems to reject the same idea, as suggested. This kind of thinking is only a pointer to the perennial problem of the objectivity of meaning, and the aeviternal struggle by philosophers (particularly in philosophy of language), to forge a leeway. To undermine the seriousness of language and to underscore the element of 'play,' Derrida sprinkles his writings with puns, plays on words, unlikely metaphors, amusing allusions, and phonic and typographical tricks [9]. This particular element of 'play' in Derrida's view of language (referring to both the lack of restraint and the lack of seriousness), has been the target of criticism, as many Marxists and feminists accuse him of an escapism. Escapism in the sense that, it becomes very difficult, to trap or pin down Derrida, even when it is crystal clear that he is ensnared. Based on his ever fleeting, maneuvering of words, conservatives and traditionalists, often accuse him of calculated nihilism. As J. H. Miller observes, deconstruction seems to push people to nihilism, which does not really bring people out of the metaphysics of essence it clamored against.

\section{Miller further writes that [28]:}

Deconstruction does not provide an escape from nihilism, nor from metaphysics, nor from their uncanny inherence in one another. There is no escape. It does, however, move back and forth within this inherence. It makes the inherence oscillate, in such a way that one, enters a strange borderland, a frontier region which seems to give the widest glimpse into the other land ("beyond metaphysics"), though this land may not by any means be entered, and does not in fact exist, for Western man.

One highly significant aspect of Derrida's writings is that, they seem to undermine the possibility of truth or absolute value; nothing can be known with certainty, thus even moral judgment becomes impossible. Reflecting on language and meaning, Derrida, concludes that language is arbitrary, imposing no limits on the play of meanings and interpretations readers may find in a text. This simply means that, there is no stable meaning in a text, but critics allege that deconstructionists inconsistently object, when they believe or notice that the true meaning of their own texts, have been wrongly interpreted. Derrida seems to be guilty of this riposte. Now, Derrida identifies texts and works of philosophers and linguists (like Plato, Edmund Husserl, Ferdinand de Saussure, Claude Levi-Strauss and so on), deconstructs their ideas, and claim that the meaning of their texts is unstable, provisional, undecided, fleeting and at best, differed. But when, John Searle attempted to pin down the meaning of his (Derrida's) own text, he complained sternly, that Searle misunderstood his position [29]. This response, indicts Derrida clearly, for that would mean that his text had 'meaning' or what Friedrich Schleiermacher (1768-1834) calls sturdy 'authorial intent' [30], which is suggestive of a fixity and decidability. If this argument holds water, then, one can argue in line with Hans-Georg Gadamer (1900-2002) that, no matter the historical or cultural context of the text, once there is a fusion of 
horizons [31], in the interpretive process, meaning, becomes the resultant corollary. However, if one decides to follow in toto the recommendations of Derrida, with regards to language and meaning, then, even the meaning of Derrida's text(s) would be unstable and differed. Thus, if I tell you that Derrida, is the simplest author to understand, I will be lying, because in truth, Derrida seems to be the simplest author to misunderstand.

Even more seriously, Deconstruction has been bemoaned for being self-contradictory, in the sense that, it asserts that, all linguistic meaning is indeterminate or uncertain. But, this assertion is strongly believed to be in itself, determinate, fixed, stable and even certain [32]. More so, while it maintains that nothing is true, the assumption or statement itself portrays an absolute true claim. Notwithstanding, this criticism, may be rebuffed, on the basis that, people who adhere to the deconstructionist project, are usually aware of the fact that, it is itself self-deconstructive. Derrida, has also been stifled by critics, with the charge of what can be called linguistic and semantic anarchism, for he holds that language is arbitrary, never founded upon stable pillars (as structuralists belief), and not bound or guided by any systematic rules; and that meaning is undecided, always differed, never fixed, provisional and thus unstable. This linguistic cum semantic anarchism, would mean the outright rejection of system buildings, homogeneity, fixity, and grand-totalizing theories. But, if this argument holds water, then as an appendage criticism, one would glaringly see that Derrida, in trying to fight the tyranny of absolutism, and in his attempt to exorcise the tradition or foundation of philosophical speculations (which privileges homogeneity of concepts, and oneness or singularity of method), ended up giving us a one "WAY" approach to language and meaning (carved on the canvas of "anything goes").

This seemingly anarchistic proposal clearly fuels the tide of calculated relativism, overpermissiveness, subjectivity and arbitrariness, in our understanding of language and the aeviternal quest for meaning. If this detection holds sway, then it would imply that Derrida has positioned a fierce barricade, enigmatic enough to place all statements, propositions, sentences, and assumptions, in philosophy and other related disciplines under the siege of undecidability. This siege of undecidability, would have sustained effect on lexicographical (dictionaries, encyclopedias, cyclopedias) and scriptural texts (Bible, Koran, Analects), and so on. Derrida might respond to this tackle, by saying that since some of the signs employed by these texts (especially the scriptural), contain transcendental signifiers, they need to be placed "sous rature", that is, "under erasure" [1]. But, is it really the case that signs, cannot be employed to reflect or speak of transcendental realities, like God, angels, Unicorn, and other celestial bodies? Derrida, may have been a thoroughgoing antimetaphysician, but to what extent can it be said that he, was free of the metaphysical pretentions, he rebuffed?

In William Lawhead's reaction, he observes that [9]:

Derrida realizes that even his own language is infected with metaphysical pretensions. The words: essence, existence, experience, consciousness, subject and object, all carry with them the baggage of thousands of years, of philosophical speculation and inescapably reflect the metaphysics of presence. Finding it impossible to critique philosophy, without employing the traditional terms of philosophy, Derrida resorts to using these words, as he says, sous rature, that is, under erasure.

Thus, when Derrida writes a word such as thing or is, he literally crosses it out, (thing, is) indicating that in using it, he is not taking it seriously. Since the word is, for Derrida, inaccurate, it is crossed out. Since it is necessary, it remains legible [1]. This is what is often regarded as the 'element of play' in Derrida's view of language (referring to both the lack of restraint and the lack of seriousness). Derrida's approach to writing, prima facie, seems unsystematic and ill-structured, for he usually does not say what he is trying to prove. On close examination, an ardent reader of Derrida, would readily discover that, his essays seem to lack, thesis statement, introduction and conclusion. This perceived vagueness, makes his text open to a pool of interpretations.

This practice could be seen as a calculated attempt, by Derrida, to make the reader(s) anticipate these things, in, of and for themselves. But this strategy often leaves the reader(s) to explore the meaning of the words, in Derrida's text, in the absence of context and structure. This seemingly Derridean unconcerned attitude, towards his readers or structure, while writing, could be based on his dogmatic belief, that structured texts are meaningless, and that the final word, or the defining 
statement about something, could never be written about anything. Thus, in the final analysis, Derrida wrote without regard for truth, since the text was all there was. And so anyone who seeks to study Derrida in order to understand, or to apprehend a final word, or discover some truthful proposition, would be exceedingly disappointed, for Derrida, leaves no foundational truth, or any fixed/stable, yet congenial, clues to the meaning he envisions. One therefore, must use his or her own ways (imagination) to decipher, whatever truths, there is to find in Derrida's text. But, once a reader arrives at meaning, it constitutes only part of the myriads of provisional meanings, which is inherent in the text; for as Derrida wills: meaning is always deferred, unstable, and undecided.

Derrida's deconstruction can also be appraised on the basis that, outside wrapping itself in mystical splendor, deconstruction only aims at dismantling traditionally held theories about language, meaning and so on, without offering any viable alternative which can withstand further vigorous analysis. In fact, some scholars seem to question Derrida's starting point, for there are noticeable instances where he is taught to have misinterpreted, misunderstood and even twisted the linguistics of Ferdinand de Saussure. It would seem that Saussure was only saying that, meaning is not outside a language, but arises from "contrast" between terms in their immediate context. But, the ingenious Derrida, seems to have replaced Saussure's idea of contrasts, with the notion of "play," which stretches out to the future limitlessly, infinitely, and indefinitely. The element of play itself, is suggestive of an empty dogmatism, lacking seriousness. Thus, if the principles of deconstruction are to be followed sanctimoniously, then, any history that relies on written texts will not be possible [28]. All texts would therefore be seen as incorrectly documented, prejudiced and uncertain. From the ex post facto, it would seem that Derrida has undermined the very ultimate search for meaning or the meaning of meaning, itself. By introducing terms, such as différance, undecidability, play, iterability, sous rature (under erasure) and so on, Derrida not only undermines the activities of philosophers (in areas such as language), but places philosophy, in its entirety, under siege.

\section{Conclusion: Making Sense of Derrida's Deconstruction project}

Let us bring this engaging discourse to a close. We set out to delineate Derrida's contributions to language and meaning. But it is always tricky to represent Derrida's ideas, because part of the purpose behind his writing is to revolt against the "violent" fixing or stabilization of meanings in language. In an intellectual operation, like a "clear explanation" or "clarification," even of Derrida, I am resorting to all kinds of violence, as I pin down and fix certain meanings to words in order for you to understand.

Gayatri Spivak avows, in the preface to Derrida's Of Grammatology thus [1]: It is inaccurate yet necessary, to say that something called De la grammatologie is (was) the provisional origin of my preface. And, even as I write, I project the moment, when you, reading, will find in my preface the provisional origin of your reading of, Of Grammatology. There can be an indefinite number of variations on that theme.

In Of Grammatology, Derrida is specifically concerned with language. But what do we study, when we study language? It would seem that, such a complex phenomenon has many aspects, and can be investigated on many levels. Derrida's immediate concern was to find the underlying "condition of all linguistic systems" [1], in other words, to uncover the minimal conditions that make language of any kind possible. This craving to unravel the nitty-gritty of linguistic systems, was forged as a result of the undue importance meted to speech (logocentrism), rather than writing. Of course, it is indeed probable that spoken language existed before written language. But Derrida speaks of the written being and the being written, which is suggestive of the notion that, even speech is first and foremost, conceived and written in the mind (air waves), before their actual concretizations with signs. And so, concentrating on speech, by contrast, readily leads to the misleading assumption, which can be summed up in his phrase "the myth (or metaphysics) of presence." Thus, from the aforementioned elucidation, all language, for Derrida, is a form of "arche-writing," marked by temporality: a succession of signs in time, spacing between signs, differences, absences, not presences. Meanings are therefore rendered as illusions of stability, through "trace". Meaning is unstable, unfixed, always differed, undecided and ever muddled. But what becomes of language?

Even more seriously, what becomes of language users? If meaning is undecided and differed, how is one expected to communicate meaningfully, in the linguistic world? How is one expected to cope 
with the pluralism of linguistic standards, and the sheer relativism that looms large? Derrida leaves a lot of questions unanswered and a lot of answers undermined. Notwithstanding (this fierce difficulty in meaningful communication), since language is a social structure, that developed long before and exists prior to our use of it, as individuals, we have to learn to use it and tap into its web of meanings, in order to communicate with others; hence, the need for deconstruction. It is this process of deconstruction, which can point the way to an understanding of language, freed from all forms of structuralism, the myth or metaphysics of presence and also open to the idea of différance. But, can deconstruction escape itself? For it would seem that, the word itself, is subject to the linguistic limitations and defects, which it purports in its own definition. Derrideans, may not necessarily view deconstruction as a concept standing outside of text, which can act upon all text without itself being affected. Deconstruction is never viewed as complete, but a continuous process: a living philosophy, constantly open to a plethora of alterations. In the final analysis, this brief glimpse of Derrida's thought is enough to give the flavor of his iconoclastic undermining of all traditional notions of truth, logic, rationality, objectivity, texts, language, meaning and interpretation. As a bona fide post-modern thinker, his deconstruction project, has had its major impact, in the field of literature, where, in the last few decades of the twentieth century, it has become one of the most important movements within literary theory.

\section{References}

[1] J. Derrida, "Of Grammatology," Spivak, G.C. (Trans.). Baltimore: The Johns Hopkins University Press, 1976.

[2] F. D. Saussure, "Course in General Linguistics," Harris, R. (trans.). London: Duckworth, 1983.

[3] F. Wilson, "Hume and Derrida on Language and Meaning," Hume Studies vol. 12, no. 2, pp. 99-121, 1986.

[4] S. Chritchley and T. Mooney, "Deconstruction and Derrida. Kearney, R. (ed.)," Routledge History of Philosophy, vol VIII: Twentieth Century Continental Philosophy. London and New York: Routledge Publishers, 2005.

[5] H. J. Silverman, Continental Philosophy II: Derrida and Deconstruction. London, New York: Routledge, 1989.

[6] J. Holcombe, Jacques Derrida. 2015. [Online]. Available: http://www.textetc.com/theory/ derrida.html. [Accessed: June. 15, 2019].

[7] D. Palmer, Looking at Philosophy. California: Mayfield Publishing Company, 1988.

[8] S. E. Stumpf, Philosophy, History and Problems. Fifth Edition. USA: McGraw-Hill, Inc, 1994.

[9] W. Lawhead, The Voyage of Discovery. USA: Wadsworth Publishing Company, 1996.

[10] D. A. Johnston, Brief History of Philosophy, From Socrates to Derrida. London: Continuum, 2006.

[11] B. Moghaddas and O. V. Dekhnich, The Philosophy of Structuralism in Language and Linguistics. [Online]. Available: https://m.cyberleninka.ru/article/n/the-philosophy-ofstructuralism-in-language-and-linguistics. [Accessed: June. 16, 2019].

[12] J. Derrida, "Of Grammatology," Spivak, G.C. (Trans.). Baltimore: The Johns Hopkins University Press, 1975.

[13] L. Guillemette and J. Cossette, Deconstruction and Différance. 2006. [Online]. Available: http://www.signosemio.com/derrida/deconstruction-and-differance.asp. [Accessed: May. 29, 2019].

[14] P. Benson, Derrida on Language. 2007. [Online]. Available: https://philosophynow.org/media/ images/regulars/icon.png. [Accessed: June. 13, 2019].

[15] J. Derrida, "Margins of Philosophy," Bass, A. (Trans.). Chicago, University of Chicago Press, 1982.

[16] J. Derrida, "Dissemination," Johnson, B. (Trans.). London: Continuum, 2005.

[17] W. A. Borody, Figuring the Phallogocentric Argument with respect to the Classical Greek Philosophical Tradition. 1997. [Online]. Available: https://kenstage.com/nebula/ feat013/agawa.pdf. [Accessed: June. 14, 2019].

[18] M. Irvine, Derrida/Deconstruction: Seminar Notes Tracing Derrida, Post-Structuralism, and Deconstruction. 2011. [Online]. Available: http://Derrida-DeconstructionNotesfiles/syllabus1. css. [Accessed: June. 10, 2019]. 
[19] E. A. Hubbard, Notes on Deconstruction: Claude Levi Strauss's “A Writing Lesson” and Jacques Derrida's Of Grammatology. 2012. [Online]. Available: https://www.scribd.com/ document/293183546/Derrida-Overview. [Accessed: June. 10, 2019].

[20] J. Derrida, "The time is out of joint. Haverkamp, A. (ed.)," Deconstruction Is/in America: A New Sense of the Political. New York: University Press, 1995.

[21] J. Derrida, "Letter to a Japanese friend. Kamuf, P. (ed.)," A Derrida Reader. New York: Harvester, 199.

[22] J. Derrida, "As if I were Dead: An interview with Jacques Derrida," Brannigan, J., Robbins, R., \& Wolfreys, J. Eds. Applying: To Derrida, London: Macmillan, 1996.

[23] C. Norris, Derrida. London: Fontana, 1987.

[24] M. Payne, Reading Theory. Oxford: Blackwell, 1993.

[25] R. Usher, and R. Edwards, Postmodernism and Education. London: Routledge, 1994.

[26] C. Norris, Deconstruction Theory and Practice. 3rd edition. London \& New York: Routledge, 2002.

[27] J. Culler, On Deconstruction: Theory and Criticism after Structuralism. New York: Cornell University Press, 1983.

[28] J. H. Miller, The Critic as Host. Bloom, H., De Man, P., Derrida, J., Hartman, G. H., Miller, J. H. (Eds), Deconstruction and Criticism. London and Henley: Routledge and Kegan Paul, 1979.

[29] J. Searle, Reiterating the Differences: A Reply to Derrida. Glyph, 1977.

[30] F. Schleiermacher, "Hermeneutics and Criticisms," Bowie, A. (trans.). Cambridge: University Press, 1998.

[31] H. G. Gadamer, Wahrheit und Methode; English translation Truth and method. 1960.

[32] J. Derrida, "Dissemination," Johnson, B. (Trans.). Chicago, University of Chicago Press, 1981. 